\title{
THE LEGAL STATUS OF HUMAN BIOLOGICAL MATERIAL USED FOR RESEARCH $H^{\star}$
}

\author{
DONRICH W THALDAR ${ }^{\dagger}$ \\ Associate Professor, School of Law, University of KwaZulu-Natal \\ BONGINKOSI SHOZI \\ Postdoctoral Scholar, University of California San Diego; \\ Honorary Research Fellow, University of KwaZulu-Natal
}

\begin{abstract}
Whether human biological material ('HBM') in the research context is susceptible of ownership is contested, yet under-investigated. This situation leads to legal uncertainty for local scientists and their international collaborators. This article presents a comprehensive analysis of the topic - investigating both common law and statutory law - and concludes that HBM in the research context is indeed susceptible of ownership. First, since the common law is dynamic, it should recognise the reality that HBM has become useful in the research context and should therefore treat HBM in this context as susceptible of being owned. This aligns with the general trend in comparative foreign case law. Secondly, since relevant statutes consistently use the legal-technical term 'donation' to denote a situation where HBM is provided by a research participant to a research institution for the purposes of research, the transfer of ownership in the donated HBM from the research participant to the research institution is a statutory requirement. This necessarily implies that HBM in the research context is indeed susceptible of ownership and, moreover, that HBM in the research context is owned by research institutions and not research participants.
\end{abstract}

Human biological material - ownership - donation - research

\section{INTRODUCTION}

(a) Problem statement and objective

The inquiry into the legal aspects of using human biological material ('HBM') in research in African countries is on the rise, occasioned by the emergence of biobanks - large-scale repositories of HBM samples - that are active in the fields of pharmacogenetics and genomics. ${ }^{1}$ In South Africa, much of the literature on biobanks has been directed at

* The work was carried out as part of the following grants: African Health Research Flagship of the University of KwaZulu-Natal; National Research Foundation grant 116275; and the WHO Epidemic Ethics initiative supported by FCDO/Wellcome Grant 214711/Z/18/Z. Funding support is gratefully acknowledged.

† BLC LLB MPPS (Pretoria) PhD (Cape Town) PGDip (Oxon). https://orcid. org/0000-0002-7346-3490.

‡ LLB LLM PhD (UKZN). https://orcid.org/0000-0003-2994-0795.

1 Francis Barchi \& Madison Little 'National ethics guidance in Sub-Saharan Africa on the collection and use of human biological specimens: A systematic review' (2016) 17 BMC Medical Ethics 64 at 64. 
perceived shortcomings in the regulatory regime. ${ }^{2}$ One pertinent issue is the contested question whether HBM in the research context is susceptible of being owned. ${ }^{3}$ The legal uncertainty around this question is undesirable. As the Nuffield Council on Bioethics puts it, 'the need to clarify the law is important insofar as its uncertainty may impede legitimate treatment, teaching, study or research or even, at worst, may encourage illegitimate uses of human tissue'. ${ }^{4}$ Given South Africa's increasingly prominent role as a site for genetic research on African populations for scientists around the world, it is in the global public interest to provide legal clarity on the legal status of HBM in the research context in South African law.

There are two apparent reasons for the current absence of scholarly consensus on the legal status of HBM in the research context in South African law. First, the country's common law on the topic is ambiguous, and since the issue has never been the subject of (reported) litigation there is no local case law to assist. Secondly, the statutory law is fragmented, sometimes contradictory, and mostly not explicit on the issue. Some scholars have looked at certain aspects, but none have attempted to provide a comprehensive analysis. However, to reach legal clarity on this issue, such a comprehensive analysis is required. This is what we intend to do in this article. ${ }^{5}$

2 See Keymanthri Moodley \& Shenuka Singh “"It's all about trust”: Reflections of researchers on the complexity and controversy surrounding biobanking in South Africa' (2016) 17 BMC Medical Ethics 57; Ciara Staunton, Paulina Tindana \& Melany Hendricks 'Rules of engagement: Perspectives on stakeholder engagement for genomic biobanking research in South Africa' (2018) 19 BMC Medical Ethics 13; Akin Abayomi, Alan Christoffels \& Ravnit Grewal 'Challenges of biobanking in South Africa to facilitate indigenous research in an environment burdened with human immunodeficiency virus, tuberculosis, and emerging noncommunicable diseases' (2013) 11 Biopreservation and Biobanking 347.

3 Academy of Science of South Africa 'Human genetics and genomics in South Africa: Ethical, legal and social implications' (2018), available at http:// research.assaf.org.za/handle/20.500.11911/106, accessed on 23 September 2020 at 85. See also Safia Mahomed, Melodie Nöthling-Slabbert \& Michael Pepper 'The legal position on the classification of human tissue in South Africa: Can tissues be owned?' (2013) 6 South African Journal of Bioethics and Law 16; D W Jordaan 'An imaginary legal conundrum: A reply to the response by Mahomed, Nöthling-Slabbert and Pepper' (2017) 107 South African Medical Journal 199.

${ }^{4}$ Nuffield Council on Bioethics 'Human tissue: Ethical and legal issues' (1995), available at https://www.nuffieldbioethics.org/publications/human-tissue, accessed on 17 December 2020.

5 Note that the conclusions reached in this article are a departure from the more traditional positions previously expressed by the first author. This is the result of the more comprehensive and in-depth nature of the analyses in this article. 


\section{(b) Road map}

In part II, we analyse the common law with reference to developments in comparative jurisdictions and conclude that a convincing argument can be made that HBM in the research context should be susceptible of ownership. In part III, we analyse statute law and reach a more decisive conclusion, namely that HBM in the research context is indeed susceptible of ownership. Our analysis of various statutes in part III also begins to paint the picture of how ownership of HBM in the research context is shaped into a unique type of ownership. In part IV, we complete this picture by analysing three ancillary issues of practical significance in the research context: how ownership in HBM is acquired; the ban on trading in (some) HBM as a qualification on ownership; and the ownership of derivative HBM such as cell lines. The analysis in part IV also illustrates the coherence of our conclusion that HBM in the research context is indeed susceptible of being owned. Finally, we conclude with a précis of our main conclusions and recommend legal reform to address problematic aspects in statutory law to solidify the legal status of HBM.

(c) A note on terminology

In this article, the following terms have the following meanings:

- 'HBM': any biological material removed from a human being, or directly or indirectly derived from such removed biological material, including sub-cellular components (such as genetic material), cells, blood, tissues, organs, gametes (sperm and ova), embryos, foetal tissues, saliva, and waste (hair, nail clippings, urine, faeces and sweat).

- 'thing': a non-specific reference to any object or entity, separate and distinct from any other object or entity. In other words, 'thing' is used in its broad general meaning, not in a legal-technical sense as implying susceptibility of ownership.

- 'research institution': any public or private entity, such as a university or private research company that conducts research using samples of HBM.

- 'research participants': living, natural persons who provide their HBM for use in research.

\section{THE COMMON LAW}

(a) The meaning of ownership

We start our discussion of common law with a few preliminary points about the concept of 'ownership'. Ownership potentially gives the owner the most complete control over a thing, and entitles the owner to deal with 
the thing as he or she pleases within the bounds of the law. ${ }^{6}$ Ownership is often conceptualised as a bundle of rights including, inter alia, the right to use, enjoy the fruits of, consume, possess, dispose of, and reclaim a thing. ${ }^{7}$ These rights are not absolute, as ownership is subject to limitation by both public law (where doing so serves the interests of society) and private law (such as in the case of land subject to a servitude). ${ }^{8}$ Such limitations may significantly diminish the actual scope of an owner's rights in relation to an owned thing. Therefore, if ownership exists in HBM, it does not follow that owners will necessarily be entitled to do as they wish with the HBM, as any of the default ownership rights can potentially be limited in various ways. ${ }^{9}$ Importantly, any limitation on ownership must be explicit. In the absence of such an explicit limitation an owner is presumed to have the full gamut of rights related to the owned thing. ${ }^{10}$

\section{(b) Susceptibility of ownership}

A thing is generally regarded as susceptible of being owned if it is: (a) independent (not part of something else); (b) not part of a natural person; (c) subject to human control (e g not the sun); and (d) useful and valuable. ${ }^{11}$ In the past, before the advent of modern medicine and modern bioscience research, the use and value of most HBM would indeed have been questionable, hence disqualifying such HBM from being owned. The obvious exception was hair that could be made into hair extensions or wigs. Other kinds of HBM, such as blood and tissue samples, only gained usefulness and value because of advances in science and technology over recent generations. However, given HBM's origin in the human body, criterion (b) - that it is not part of a natural person - remains controversial and requires further analysis.

${ }^{6}$ Cornelius van der Merwe 'Things' in W A Joubert (founding ed) The Law of South Africa vol 272 ed (2014) para 134.

7 Ibid para 135.

8 Ibid para 139.

9 In many cases the law relating to HBM does prescribe on these issues, as we discuss below.

10 This is particularly the case in jurisdictions such as South Africa where the right to property is subject to constitutional protection. See s 25 of the Constitution of the Republic of South Africa, 1996.

11 Note that some leading authors also include corporeality as a criterion for susceptibility of ownership; however, this is not generally accepted. In any event, since HBM is corporeal, the inclusion or exclusion of this criterion will not detract from our thesis that HBM is susceptible of being owned. As such, we do not need to engage in the debate about this controversy in South African law, on which see Anne Pope \& Elmien du Plessis (eds) The Principles of the Law of Property in South Africa 2 ed (2020, e-pub) 40; Van der Merwe op cit note 6 para 18. 
Due to its colonial past, South Africa's common law is primarily founded on the principles of Roman-Dutch law. ${ }^{12}$ As such, criterion (b) is traced back to the Roman law principle that no one is to be regarded as the owner of his or her own limbs. ${ }^{13}$ It is debatable exactly how this principle would apply to HBM: is the principle applicable only to one's limbs that are part of one's body, or also to one's limbs that have been removed from one's body? Since human hair was bought and sold in Roman times ${ }^{14}$ — as it is today - it constitutes at least one kind of HBM that was and is susceptible of ownership. This implies that one or both of the following answers to the question above must be true: that the principle does not apply to one's limbs that have been removed from one's body, or that Roman law allowed for exceptions to the general principle. Since no South African court has yet considered the application of this principle to HBM, this topic remains unsettled. ${ }^{15}$ However, it is well-established legal precedent that South African courts can benefit from considering the arguments in foreign case law - to the extent that such arguments are relevant to South African law, of course. ${ }^{16}$ Given that the Roman law principle that no one is to be regarded as the owner of his or her own limbs was received into both English common law ${ }^{17}$ and Scots law, ${ }^{18}$ we focus on case law in these legal systems.

\section{(c) Comparative analysis of case law}

There are excellent comparative studies of case law on ownership of HBM in various jurisdictions. ${ }^{19}$ We do not intend to provide an in-depth analysis of every case, but rather to identify the main findings. Many of the cases do not deal with HBM in the research context specifically, but in other

12 See for example Paulsen v Slip Knot Investments 777 Pty Ltd 2015 (3) SA 479 (CC). Note, however, that in 1806 the Cape Colony passed from Dutch to British rule, ushering in an era of English common-law influence. As a consequence, South African law is often described as a 'hybrid' or 'mixed' legal system. For example, South African law adheres to stare decisis, similar to common-law jurisdictions.

13 Dominus membrorum suorum nemo videtur: D.9.2.13pr.

${ }^{14}$ For instance, in The Art of Love (Ars Amatoria 3.165), Ovid refers to 'bought braids' ('crines empti'). On the topic of the use of human hair in ancient Rome in general, see: Elizabeth Bartman 'Hair and the artifice of Roman female adornment' (2001) 105 American Journal of Archaeology 1.

${ }^{15}$ Magda Slabbert 'This is my kidney, I can do what I want with it - Property rights and ownership of human organs' (2009) 30 Obiter 499 at 516.

16 Kv Minister of Safety and Security 2005 (6) SA 419 (CC) paras 34-5.

17 See James Edelman 'Property rights to our bodies and their products' (2015) 39 University of Western Australia Law Review 47 at 50.

18 See: Kenneth Reid 'Body parts and property' in Roderick Paisley \& Douglas Bain (eds) Northern Lights: Essays in Private Law in Memory of Professor David Carey Miller (2018) Edinburgh School of Law Research Paper No 2015/25 at 9, available at $h t t p: / / d x$.doi.org/10.2139/ssrn.2644303, accessed on 10 February 2021.

19 See for example Edelman op cit note 17. 
contexts such as diagnostic tests and reproduction. However, we include these cases since they speak to the same foundational legal question.

In England, the 1998 judgment in $R v$ Kelly and Lindsay ${ }^{20}$ provides an obiter dictum that nods in the direction of recognising ownership in HBM in the research context based on its usefulness:

'Furthermore, the common law does not stand still. It may be that if, on some future occasion, the question arises, the courts will hold that human body parts are capable of being property ... even without the acquisition of different attributes, if they have a use or significance beyond their mere existence. This may be so if, for example, they are intended for ... the extraction of DNA .... ${ }^{21}$

The usefulness of HBM for DNA testing was indeed part of the ratio decidendi in the 2000 Australian case of Roche $v$ Douglas. ${ }^{22}$ The Supreme Court of Western Australia was seized with the question whether tissue samples of a deceased person that were taken for diagnostic purposes before his death are susceptible of ownership. The background to the case was a paternity dispute, and the tissue samples could be used for DNA testing to settle the dispute. In light of the proliferation of this new technology that makes HBM useful - at least in certain contexts, such as in the context of the case - the court remarked that the 'world has moved on'23 and held that the tissue samples are indeed susceptible of ownership. It expanded on its reasoning as follows:

'In the wider sense, it defies reason to not regard tissue samples as property. Such samples have a real physical presence. They exist and will continue to exist until some step is taken to effect destruction. There is no purpose to be served in ignoring physical reality. To deny that the tissue samples are property, in contrast to the paraffin in which the samples are kept or the jar in which both the paraffin and the samples are stored, would be in my view to create a legal fiction. There is no rational or logical justification for such a result. ${ }^{24}$

The 2005 Canadian case of $C C v A W^{25}$ centred on a dispute regarding frozen embryos. The Court of Queen's Bench of Alberta treated the embryos and the preceding gametes as susceptible of ownership. It determined ownership of the embryos based on the characterisation of the prior provision of sperm by the one party (the man) as an 'unqualified gift' to the other party (the woman). South African statutory law on artificial fertilisation explicitly provides that gametes and in vitro embryos

20 [1999] QB 621.

21 Ibid.

22 [2000] WASC 146, (2000) 22 WAR 331.

23 Ibid para 22.

24 Ibid para 24.

252005 ABQB 290. 
are owned by specified persons, hence settling this possible debate in South African law. ${ }^{26}$

An oft-cited case on HBM's susceptibility of ownership is the 2008 English case of Yearworth $v$ North Bristol NHS Trust. ${ }^{27}$ Although it dealt with sperm in the reproductive context, its reasoning can be applied more broadly. The facts, in brief, were as follows. Six men - all diagnosed with cancer and having to undergo chemotherapy — provided semen samples that were stored for later use at a hospital. However, the hospital's negligence caused the sperm to perish. The five surviving men and the estate of the sixth deceased man sued for damages. In its judgment, the England and Wales Court of Appeal (Civil Division) recognised the similarity between the English common-law position and the Roman law principle that no one is to be regarded as the owner of his own limbs. ${ }^{28}$ Based on the 1908 judgment in Doodeward $v$ Spence, ${ }^{29}$ ownership in HBM was only deemed possible if 'work and skill' were applied to HBM. However, the court in Yearworth held that 'developments in medical science now require a reanalysis of the common law's treatment of and approach to the issue of ownership of parts or products of a living human body'. ${ }^{30}$ As such, the court shifted the focus away from the work-and-skill test and focused on a 'broader basis' to establish ownership in HBM. ${ }^{31}$ The court relied on a number of facts as indiciae of ownership, including the fact that the men generated the sperm, that they intended to use the sperm for their own benefit, and that they were the only rights-holders with relation to the sperm, and concluded that the men had ownership of the sperm. ${ }^{32}$ Importantly, the court differentiated Yearworth from cases where HBM is not intended for use by the persons from whose bodies the HBM was removed, and made it clear that its conclusion that ownership vests in the generator of the sperm is not applicable to such cases. ${ }^{33}$

26 Regulation 18 relating to the Artificial Fertilisation of Persons in GN R175 GG 35099 of 2 March 2012. For an analysis of the ownership of embryos in South African law, see Robbie Robinson 'The legal nature of the embryo: Legal subject or legal object?' (2018) 21 PER/PELJ available at https://doi. org/10.17159/1727-3781/2018/v21i0a2914, accessed on 10 February 2021; Donrich Thaldar 'The in vitro embryo and the law: The ownership issue and a response to Robinson' (2020) 23 PER/PELJ available at https://doi. org/10.17159/1727-3781/2020/v23i0a6217, accessed on 10 February 2021.

27 [2009] EWCA Civ 37, [2010] QB 1.

28 Ibid para 30.

29 (1908) 6 CLR 406 at 415.

30 Yearworth supra note 27 para 45(a).

31 Ibid para 45(e).

32 Ibid para $45(f)$.

33 Ibid para 45(b). 
Yearworth proved to be influential in subsequent cases in Australia ${ }^{34}$ and Canada $^{35}$ that also dealt with sperm in the reproductive context - all of which reached the conclusion that sperm is susceptible of ownership. However, the 2013 Scottish judgment in Holdich v Lothian Health Board ${ }^{36}$ was less enthusiastic about Yearworth. Although the facts of these two cases were almost identical, the nature of the cases was different. While the Yearworth judgment was a final adjudication on the merits of the claim, Holdich was an interlocutory judgment on whether the case disclosed a cause of action and could proceed to a full trial. The cause of action relied, inter alia, on the susceptibility of sperm of ownership in Scots law, which the opposing party disputed. While falling short of endorsing the susceptibility of sperm of ownership, by ruling that the case could proceed to the main hearing, the court in Holdich signalled that the susceptibility of sperm of ownership was, in principle, possible in Scots law. The court held that ' $[\mathrm{t}]$ he case raises questions of novelty and importance in a developing area of law which demand to be answered after all the facts are known'. Alas, the case subsequently settled out of court before the full trial and a potentially more decisive judgment. ${ }^{37}$

Nevertheless, it is interesting to note why Holdich did not follow Yearworth. Although Holdich adopted the Yearworth approach of looking at the actual rights of the man who generated and stored the sperm as possible indiciae of ownership, its assessment of these rights was different from that in Yearworth. Because of various statutory restrictions on the use of sperm, the court in Holdich considered the 'possible conclusion that the postulated property right of gamete providers is so attenuated that it is a distortion to describe it as a right of property at all'. As some of the literature on the topic observes, this approach adopted in both Yearworth and Holdich to treat rights that emanate from ownership as indiciae of ownership is misguided, as it confuses cause with effect. For example, the right to use a thing is a consequence of ownership, not its cause. ${ }^{38}$ This, we suggest, is a valid critique of both Yearworth and Holdich. To build on this critique with a general example, in instances of usufruct the owner is left with nuda proprietas,

34 Bazley v Wesley Monash IVF Pty Ltd [2010] QSC 118 (TD); Roblin v The Public Trustee for the Australian Capital Territory [2015] ACTSC 100.

35 JCM v ANA 2012 BCSC 584; Lam v University of British Columbia 2015 BCCA 2.

36 [2013] CSOH 197, 2014 SLT 495.

37 Holdich was the lead case for a number of pursuers (plaintiffs/claimants) who claimed that their stored sperm had been or might have been damaged due to the same freezer malfunction. Within three months of the Holdich decision, all the claims were settled. As such, the case never proceeded to full trial. (Personal correspondence with Steven Love QC (28 January 2021) and David Stephenson QC (27 January 2021), who served as counsel for the pursuer and defenders respectively.)

38 Reid op cit note 18 . 
entailing very few residual ownership rights. If the Yearworth approach were applied, the usufructuary would seem to be the owner. Accordingly, the Yearworth approach should not be followed in South Africa. This does not mean that the conclusion in Yearworth regarding the susceptibility of the sperm of ownership was incorrect. Instead, the same conclusion could have been reached in a logically coherent manner by applying the rationales in Kelly and Roche - that is, by recognising the reality that sperm is a thing separate from the human body, such as the plastic straw in which it is stored or the jar in the Roche judgment, and that given developments in modern medicine the sperm has usefulness and value.

\section{(d) Conclusion}

The general trend in these comparable jurisdictions toward the recognition of HBM as susceptible of ownership is noteworthy. The elements that stand out are: the dynamic nature of the common law to cater for new developments in society; the recognition of the reality that HBM has become useful in certain contexts, such as research; and the consequent need to reconsider the historical exclusion of HBM from ownership and to align the common law with current reality. We suggest that these elements provide a compelling argument in favour of a similar recognition of HBM as susceptible of ownership in South African common law. ${ }^{39}$

\section{STATUTORY LAW}

\section{(a) Introduction}

The main source of the South African statutory law on HBM in the research context is the National Health Act 61 of 2003 ('NHA') and its relevant subsidiary legislation. The relevant subsidiary legislation includes the Regulations regarding the General Control of Human Bodies, Tissue, Blood, Blood Products and Gametes ('General Control Regulations'), ${ }^{40}$ the Regulations relating to the Use of Human Biological Material ('Use of Human Biological Material Regulations'), ${ }^{41}$ and the Regulations relating to Research with Human Participants ('Human Research Participants Regulations'). ${ }^{42}$ In addition, the Department of Health's ethics guidelines

39 The indiciae approach introduced in Yearworth supra note 27 is not only erroneous but, we suggest, it was also unnecessary for a court to develop the common law and reach the same conclusion. The elements identified above are sufficient.

${ }^{40}$ Regulations regarding the General Control of Human Bodies, Tissue, Blood, Blood Products and Gametes in GN R180 GG 35099 of 2 March 2012.

41 Regulations relating to the Use of Human Biological Material in GN R177 GG 35099 of 2 March 2012.

${ }^{42}$ Regulations Relating to Research with Human Participants in GN R719 GG 38000 of 19 September 2014. 
('Department of Health Guidelines') ${ }^{43}$ are made legally binding on researchers by the Human Research Participants Regulations, ${ }^{44}$ and can therefore be seen as a quasi-statute and part of the NHA's subsidiary legislation. Lastly, another document that gains its legal force from the NHA is the Material Transfer Agreement for Human Biological Materials ('SA MTA'). ${ }^{45}$ The SA MTA must be used as a 'framework' by all providers and recipients of HBM for use in research or clinical trials. Hence, it indirectly provides another layer of legal rules and can also aptly be described as a quasi-statute. We refer collectively to these statutes and quasi-statutes as the 'statutory scheme'.

\section{(b) Statutory definitions}

The statutory scheme uses two different lexicons to refer to HBM and categories of material within the broader concept. In this part of the article, we analyse this duality. We commence with the primary legislation, namely the NHA. Interestingly, the NHA does not use the term 'human biological material'; instead, it retains a lexicon that it inherited from one of its processor statutes, the Human Tissue Act 65 of 1983. This lexicon includes, most prominently, the terms 'tissue', 'blood', 'blood products', and 'gametes'. Three of these terms are defined in the NHA:

- 'blood product' means 'any product derived or produced from blood, including circulating progenitor cells, bone marrow progenitor cells and umbilical cord progenitor cells'.

- 'gamete' means 'either of the two generative cells essential for human reproduction'.

- 'tissue' means 'human tissue, and includes flesh, bone, a gland, an organ, skin, bone marrow or body fluid, but excludes blood or a gamete'.

In the context of modern health research, the crucial question is: does 'tissue' include individual cells derived from tissue samples and individual sub-cellular components of cells such as DNA? 'Tissue' is normally understood as an aggregate of cells with the same function, at an organisational level above that of individual cells, and below that of organs. ${ }^{46}$

However, the NHA's definition of 'tissue' appears to be broader than its normal meaning, as it includes things such as 'organs', 'glands',

43 Department of Health of South Africa Ethics in Health Research: Principles, Processes and Structures 2 ed (2015).

44 Regulation 2(a) of the Human Research Participants Regulations.

45 Material Transfer Agreement for Human Biological Materials in GN 719 GG 41781 of 20 July 2018.

${ }^{46}$ Harvey F Lodish (ed) Molecular Cell Biology 6 ed (2008) 801; Gerard J Tortora \& Bryan Derrickson Principles of Anatomy and Physiology 12 ed (2010) 4. 
and 'body fluid'. Yet, there is nothing to indicate that such broadening also includes individual cells or their sub-cellular components. In this context, the following distinction is important: (a) HBM that is of a kind that is normally removed from persons in the healthcare context ('non-derivative HBM'), and (b) HBM that is of a kind that is directly or indirectly derived from (a) in a laboratory, such as individual cells or their sub-cellular components ('derivative HBM' or 'derivatives' in short). This is an important distinction, as legal rules that are applicable to one kind of thing are not eo ipso applicable to the kinds of things that can be derived from the former kind. For instance, a legal rule that motor vehicles must be licensed before they may be used on a public road would be applicable to motor vehicles, not to spark-plugs, and not to recycled metal. In this light, note that the things listed in the definition of 'tissue' are examples of (a), not of (b). It must therefore be concluded that 'tissue' as per the NHA does not include derivatives such as individual cells or sub-cellular components of cells.

The term 'human biological material' was first introduced to South African statute law with the promulgation of the Use of Human Biological Material Regulations - nine years after the enactment of the NHA. ${ }^{47}$ These regulations define 'biological material' as 'material from a human being including DNA, RNA, blastomeres, polar bodies, cultured cells, embryos, gametes, progenitor stem cells, small tissue biopsies and growth factors from the same'. ${ }^{48}$ The use of the word 'including' suggests that the list is illustrative, rather than closed. ${ }^{49}$ This impression is strengthened by the fact that although blood is not specifically listed, the Use of Human Biological Material Regulations elsewhere refer to the withdrawal of blood as a kind of withdrawal of HBM. ${ }^{50}$

An important difference between the definitions of tissue and of biological material relates to derivatives. Apart from the fact that HBM in its normal meaning is sufficiently broad to include derivatives, its statutory definition specifically includes examples of such derivatives, such as DNA and RNA. Note that only derivatives that are themselves biological material (i e substances that are present in or produced by a living human being) are included; incorporeal derivatives, such as a person's genome sequence or a unique allele, are not included. ${ }^{51}$

47 Use of Human Biological Material Regulations.

48 Ibid reg 1.

49 This conclusion is also in accordance with the principles of statutory interpretation. See Minister of Safety and Security v Xaba 2003 (2) SA 703 (D) at 713GE-714B.

50 Use of Human Biological Material Regulations, reg 1 (definition of 'competent person') read with reg 2(a).

51 A person's genetic information would fall within the regulatory ambit of the Protection of Personal Information Act 4 of 2013 ('POPIA'). The relevant 
While the NHA's lexicon is followed in the General Control Regulations, the Use of Human Biological Material Regulations' lexicon is followed in the Department of Health Guidelines and the SA MTA. While both the Department of Health Guidelines and the SA MTA duplicate the definition of the Use of Human Biological Material Regulations, each adds to the list of examples: the Department of Health Guidelines add 'blood and blood products', and the SA MTA adds 'and any modifications or derivatives thereof'. Although these do not feature in the illustrative list provided in the Use of Human Biological Material Regulations' definition of 'biological material', they are included in its meaning. As such, they serve to clarify the definition, but do not change its meaning.

The different lexicons make the statutory scheme difficult to navigate. From the perspective of legal certainty, the statutory scheme would benefit from having a single lexicon that is used uniformly throughout all its constituent legislation. Moreover, it would assist if more comprehensive definitions are provided, rather than overly brief abstract descriptions followed by lists of examples. However, for now, we analyse the law as we find it.

\section{(c) HBM is susceptible of ownership}

Neither the NHA nor any of its regulations expressly address the issue of ownership of HBM. This silence is broken in the SA MTA, which we discuss below. We first discuss the NHA and its regulations. These statutes consistently use the term 'donation' to denote a situation where tissue, gametes, blood or blood products (where the NHA's lexicon is used) or HBM (where the Use of Human Biological Material Regulations' lexicon is used) is provided by a research participant to a research institution ${ }^{52}$ for the purposes of research. ${ }^{53}$ At common law, 'donation' is a legal/technical term for a particular type of contract that entails a donor undertaking to give something to a donee without the donor receiving any consideration in return or the expectation of a future advantage. ${ }^{54}$ Importantly, performance in terms of a donation - delivering the donated thing entails the transfer of ownership in the donated thing from the donor to

provisions of POPIA entered into force on 1 July 2020 (Proc R21 GG 43461 of 22 June 2020) and came into effect from 1 July 2021.

52 Regulation 4 of the General Control Regulations provides a list of the institutions to which specific tissue, blood, blood products or gametes from a living person may be donated. This list includes, inter alia, an authorised institution. An authorised institution is an institution that is designated as such by the Minister of Health in terms of s 54 of the NHA. We refer to all the institutions in this list collectively as 'research institutions'.

53 Section 60(4)(a) of the NHA; reg 4 of the General Control Regulations; regs 1 and 11 of the Use of Human Biological Material Regulations.

${ }_{54}$ L T C Harms 'Donations' in W A Joubert (founding ed) The Law of South Africa vol 163 ed (2017) para 19. 
the donee. ${ }^{55}$ Accordingly, the use of the term 'donation' in these statutes necessarily implies that HBM is susceptible of ownership.

Next, we analyse three prominent aspects of the statutory scheme in the light of the above.

\section{(d) Ownership and exclusive rights}

Applied to the research context, reg 26 of the General Control Regulations provides that when tissue, ${ }^{56}$ blood or gametes is donated to a research institution for the purpose of research, the research institution acquires 'exclusive rights' in the HBM - provided that the research institution actually uses such HBM for the purpose of research, and subject to any restrictions in terms of the NHA or any other law. ${ }^{57}$ Note that tissue, ${ }^{58}$ blood and gametes constitute all the non-derivative HBM contemplated in the two statutory lexicons. In other words, reg 26 effectively covers the widest possible array of HBM contemplated in the statutory lexicons that can potentially be donated by a research participant. What is notable for present purposes is that the formulation of reg 26 uses neither 'ownership' nor 'transfer', but 'exclusive rights' and 'acquire' instead. But is the acquisition of exclusive rights compatible with the transfer of ownership in terms of a contract of donation?

We suggest an affirmative answer: reg 26 makes it clear that any and all rights there might be in the tissue, blood or gametes that are provided for research vest in the research institution. In no way does this exclude ownership. The default content of full ownership would be similar to that of exclusive rights in the present context, as both would entail all the relevant rights that a person can have in a thing, subject only to the legal restrictions on the use of the particular thing. Importantly, while ownership can be qualified by transferring specific rights entailed by (full) ownership to other persons and still be referred to as 'ownership', 59 the concept of exclusive rights is stronger, as it makes it clear that no other person enjoys any rights regarding the relevant thing. Accordingly, reg 26 is not only compatible with the transfer of ownership in terms of a contract of donation, but it also goes a step further.

55 Ibid.

56 Tissue as defined in the NHA.

57 Regulation 26 of the General Control Regulations.

58 Tissue as defined in the NHA.

59 For instance, one remains the owner of one's property despite a mortgage over the property that limits one's right to alienate the property. 
(e) Withdrawal by a research participant

Regulation 5(f) of the Human Research Participants Regulations provides that a research participant is free to withdraw from a research project without penalty or reason. ${ }^{60}$ Is this provision compatible with the transfer of ownership in terms of a contract of donation? To answer this question, one must first determine what will be the impact of withdrawal on the already donated HBM. The Department of Health Guidelines provide that in the event of a research participant withdrawing from a research project, the 'unused identifiable material' must be destroyed, but not any possible 'immortalised cell line based on the specimen'. If a legal rule can be generalised from this provision, it is that reg $5(f)$ effectively gives the research participant a right to destroy the original HBM, but not the derivatives therefrom. The right is non-exclusive, because there is nothing prohibiting the research institution qua owner of the original HBM from destroying it, for instance at the end of a research project. Now, to answer the question posed above: the research participant's non-exclusive right to destroy the original donation is entirely compatible with transfer of ownership in terms of a contract of donation, as it changes only the naturalia, but not the essentialia of the contract of donation. Stated differently, the research participant's non-exclusive right to destroy the original donation amounts to a qualification of the research institution's ownership. And, as discussed in part II, the limitation on the exercise of ownership rights does not exclude such ownership. ${ }^{61}$

Given the stronger nature of exclusive rights, however, the research participant's non-exclusive right to destroy the original donation is in apparent conflict with the general rule established in reg 26 of the General Control Regulations, namely that the research institution acquires exclusive rights in donated tissue, blood or gametes. The solution to this conflict between these two sets of regulations is found in the internal qualifier of reg 26: exclusive rights are acquired subject to any restrictions in terms of the NHA or any other law. This is clearly such a case. The research participant's non-exclusive right to destroy the original donation is a restriction in terms of extant law, and hence constitutes an exception to the general rule that the research institution acquires exclusive rights in donated tissue, blood or gametes. Notably, this is the only instance in extant law where the research participant has a right that qualifies the general rule established in reg 26. The ways in which a research institution's exclusive rights (and ownership) are qualified through legal norms more generally are analysed in part IV below.

${ }^{60}$ Regulation 5(f) of the Human Research Participants Regulations.

${ }^{61}$ See the sub-part under the heading 'The meaning of ownership' above. 


\section{(f) Perpetual donor ownership?}

At the time of its promulgation, the SA MTA was the first instrument in the statutory scheme explicitly to refer to ownership of HBM - but not in an entirely helpful way. It provides in para 3.3 that 'the donor remains the owner of the material until such materials are destroyed'. ${ }^{62}$ While para 3.3 confirms that HBM is indeed susceptible of ownership, it purports to introduce perpetual ownership by research participants of HBM. The notion of ownership remaining with the donor of a donated thing is alien to South African law, and therefore contrary to the legislative purpose of using the term 'donation' in the NHA and its regulations. It follows that para 3.3 of the SA MTA is invalid to the extent that it purports to stop the transfer of ownership of HBM by research participants to research institutions.

It should also be noted that para 3.3 of the SA MTA is in any event not peremptory, but optional, for reasons we shall expand upon presently. In para 1 , the SA MTA provides that its objective is to set out a 'framework within which the Parties will engage in the transfer, use and other processing of the Materials' ${ }^{63}$ If the legislative purpose is that the SA MTA must be a 'framework', it means that the substantive content of each term of the agreement is not intended to be peremptory, but is rather intended to be customisable - provided that the general or basic structure of the SA MTA remains intact. Essentially, the only peremptory aspects of the SA MTA are that whenever HBM is shared for use in research or clinical trials, a material transfer agreement ('MTA') must be in place, and such an MTA must cover all the topics that are covered in the SA MTA. Accordingly, para 3.3 is not peremptory, but is rather intended as an optional term that parties can decide to include, change, or simply exclude. Given our conclusion above, namely that para 3.3 is invalid to the extent that it purports to stop the transfer of ownership of HBM by research participants to research institutions, parties to an MTA who wish to include a term about ownership should change the wording of para 3.3 to eliminate the notion of perpetual donor ownership. Furthermore, such an amended term should also align with reg 26 of the General Control Regulations, entailing that research participants cannot retain any residual rights in donated tissue, blood or gametes, except where the law makes provision for research participants to do so. ${ }^{64}$ As discussed above,

62 SA MTA para 3.3.

63 Ibid para 1.

64 Other papers have highlighted the apparent misalignment between para 3.3 of the SA MTA and reg 26 of the General Control Regulations. See Donrich Thaldar, Marietjie Botes \& Annelize Nienaber 'South Africa's new standard material transfer agreement: Proposals for improvement and pointers for implementation' (2020) 21(85) BMC Medical Ethics available at https://doi.org/10.1186/s12910-020-00526-x, accessed on 10 February 2021; 
there is only one such exception of a residual right retained by the research participant, namely the right to withdraw from a research project and to have the original donated HBM destroyed.

\section{(g) Conclusion}

Our analysis of the statutory law in part III goes an important step further than our analysis of the common law in part II. Whereas our analysis of the common law concludes that it should be developed to recognise ownership of HBM in the research context, our analysis of statutory law reaches a more decisive and immediate conclusion, namely that HBM in the research context is susceptible of ownership. Moreover, our analysis of statutory law has also revealed that the legal nature of the transaction when research participants provide their HBM to research institutions is donation. Importantly, because this is provided in primary legislation, any provision in subsidiary legislation that does not accord with it would automatically be invalid. Accordingly, we analysed three relevant provisions in subsidiary legislation: reg 26 of the General Control Regulations, reg 5(f) of the Human Research Participants Regulations, and para 3.3 of the SA MTA. While the first two provisions are in accordance with the primary legislation, the latter provision is discordant with it, and hence invalid to the extent of discordancy.

\section{ANCILLARY ISSUES}

Now that we have established that HBM in the research context is susceptible of ownership and that the nature of the transaction between the research participant and research institution is donation of the HBM, we analyse some salient ancillary issues. The purpose is to understand more fully the nature of ownership of HBM as a unique type of ownership. The ancillary issues that we analyse are: the acquisition of ownership in HBM; the ban on trading in (some) HBM as a qualification on ownership; and the ownership of derivatives.

\section{(a) Acquiring ownership of HBM}

Legal doctrine requires that one must be the owner of a thing as a necessary precondition to transfer ownership of the thing. ${ }^{65}$ Applied to the context of donation of HBM for research, this legal doctrine requires

Donrich Thaldar 'One material transfer agreement to rule them all? A call for revising South Africa's new standard material transfer agreement' (2020) 7(105) Humanities and Social Sciences Communications available at https://doi.org/10.1057/ s41599-020-00600-0, accessed on 10 February 2021.

65 This is in accordance with the maxim nemo plus iuris ad alium transfere potest, quam ipse haberet. See e g Van der Merwe v Taylor 2008 (1) SA 1 (CC) para 40 n 45 . 
that there must be original acquisition of ownership of the HBM by the research participant (donor) as a precondition for the derivative acquisition of ownership of the HBM by the research institution (donee). There are various modes of original acquisition at common law, but none of them has been applied to HBM in South African law. This raises the question: how exactly does the research participant become the owner of the HBM? We suggest that the relevant statute - the NHA and its regulations create a new mode of original acquisition applicable to HBM in the research context, in terms of which the research participant is automatically the owner of the HBM removed from his or her body for the purpose of research. This is analogous but obviously not similar to fruit, which at common law is automatically owned by the owner of the principal thing upon separation. This construction is necessary as it allows the research participant qua donor to intend to give away his or her HBM without compromising his or her own ex lege original acquisition. Such subjective intention eliminates original acquisition through appropriation (Latin: occupatio), as appropriation requires the subjective intention to be the owner. It would be paradoxical (or a change of intention) for a research participant to provide informed consent to donate a blood sample but then, at the moment when the nurse withdraws the blood, have the intention to be the owner of the blood. Another possible common-law mode of original acquisition that might be applicable is specification (specificatio). However, given that it is often somebody acting on behalf of the research institution qua donee, such as the nurse in the example above who removes the HBM, specification also fails to provide a general solution for original acquisition of ownership by the donor. In any event, specification requires the making of a new thing without an agreement to such effect, and can therefore only be applicable in the absence of a valid donation agreement. We discuss this possibility below. It must be concluded, therefore, that the NHA and its regulations established a new mode of original acquisition applicable to HBM in the research context, entailing that the research participant is automatically the owner of HBM that is removed for the purpose of research.

We now focus on the derivative acquisition of ownership by the research institution qua donee. Derivative acquisition of ownership occurs, as a general rule, when the object of ownership is delivered. How does delivery take place in the context of donation of HBM for research? We analyse this question with reference to three scenarios:

- Scenario I: A research participant does a cheek swab him- or herself, and then hands the swab to a representative of the research institution.

- Scenario II: A representative of a research institution draws a blood sample from a research participant.

- Scenario III: A woman who has undergone in vitro fertilisation decides to donate her remaining embryos for research. 
In Scenario I, the apparent moment of delivery is when the swab is handed over. However, another possibility is to perceive the research participant as doing the cheek swab on behalf of the research institution, in which case delivery would coincide with removal of the HBM from the research participant's body. Such synchronicity of the acts of removal and delivery is inherent in Scenario II, where a representative of a research institution draws a blood sample from a research participant. Scenario III is more complicated, as HBM is not removed from a research participant's body for the purpose of research. Rather, gametes are removed from persons' bodies and in vitro embryos are created for the purpose of procreation. As mentioned above, gametes and in vitro embryos in the reproductive context are governed by a separate set of regulations that provide that these things are owned by specified persons. ${ }^{66}$ Embryos are owned by the woman for whose artificial fertilisation the embryos were created. However, since the embryos would be in the possession of a fertility clinic and might be donated to the same fertility clinic, no physical act of delivery will take place. But, since the law recognises various modes of constructive delivery, delivery can legally be deemed to take place based on agreement to such effect. The mode of constructive delivery in Scenario III would be traditio brevi manu. ${ }^{67}$

The derivative acquisition by a research institution of HBM is, however, subject to specific statutory requirements. HBM may only be removed from a person if such person provides written informed consent, ${ }^{68}$ and only if the removal serves one of the purposes that is provided for in delegated legislation in terms of the NHA, ${ }^{69}$ one of which is research. ${ }^{70}$ If these requirements are not complied with, the act of removal - the essential act to perform in pursuance of a contract of donation of HBM would be illegal. Since, as a general rule, a contract to perform an illegal act is void ab initio, the purported donation would be void and although the research institution would be in physical possession of the HBM, ownership would not have been transferred and the research participants would retain ownership. If the research institution is a bona fide possessor, it will acquire ownership through prescription after 30 years. This would

${ }^{66}$ Regulation 18 of the Regulations relating to the Artificial Fertilisation of Persons in GN R175 GG 35099 of 2 March 2012. For an analysis of the ownership of embryos in South African law, see Robinson op cit note 26; Thaldar op cit note 26.

67 Van der Merwe op cit note 6 para 223.

${ }^{68}$ Sections 7 and 55(a) of the NHA; reg 3(1)(a) of the Use of Human Biological Material Regulations.

${ }^{69}$ Sections 55(b) and 56(1) of the NHA; reg 5 of the Use of Human Biological Material Regulations.

70 Regulation 5(b) of the Use of Human Biological Material Regulations. This is also implicit in the Human Research Participants Regulations. 
be the case if, for instance, the consent was somehow defective, although the research institution in good faith believed it to be in order. If such a state of affairs comes to light (for instance, to build on the previous example, if research participants prove in court that the 'consent' that they provided was in fact defective), would the research institution still be able to acquire ownership ex post facto? We suggest yes. The path to acquiring ownership would be for the research institution first to comply fully with the statutory requirements (i e obtain written informed consent to research participation) and then to request the research participants to donate the HBM that has already been removed. Although the unlawfulness (and possible criminal-law consequences) of the removal per se will not be erased, there is nothing in the law that prohibits the donation of already removed HBM for research purposes.

But what of the sharing of HBM between research institutions? While the law prescribes that the provision of $\mathrm{HBM}^{71}$ for research by a research participant is donation, the law does not make a similar prescription where HBM is provided for research by a research institution. This means that the parties to such sharing of HBM have the freedom to decide whether the providing research institution retains ownership, or whether the providing research institution transfers ownership to the recipient research institution.

In conclusion, we have discussed the SA MTA above and pointed out that its ownership clause is in conflict with the primary legislation, and is hence invalid, and that its substantive terms are in any event optional. Accordingly, the SA MTA has little to contribute to the present context. More useful to note is that the most well-known international standard MTAs - the Uniform Biological Material Transfer Agreement ('UBMTA'), ${ }^{72}$ the AUTM MTA for Human Tissues, ${ }^{73}$ and the United States National Institutes of Health ('NIH') ${ }^{74}$ Simple Letter Agreement

71 This includes those kinds of HBM included in the quartet of terms of the NHA's lexicon.

72 'Uniform Biological Material Transfer Agreement' ('UBMTA') available at https://autm.net/surveys-and-tools/agreements/material-transfer-agreements/mta-toolkit/ uniform-biological-material-transfer-agreement/, accessed on 10 February 2021, or https:// www.wipo.int/tk/en/databases/contracts/texts/ubmta.html, accessed on 10 February 2021.

73 'Standard Material Transfer Agreement For the Transfer of De-identified Human Tissues and Specimens Between Non-profit Organizations' ('AUTM MTA') available at https://autm.net/surveys-and-tools/agreements/materialtransfer-agreements/mta-toolkit/autm-mta-templates, accessed on 10 February 2021.

${ }^{74}$ The NIH is the biggest provider of research grants for public and philanthropic health research globally. In 2016 it was reported that the NIH annually provides US $\$ 26.1$ billion in research grants. See R F Viergever \& T C Hendriks 'The 10 largest public and philanthropic funders of health research in the world: What they fund and how they distribute their funds' (2016) 14(12) Health Research Policy and Systems available at https://doi.org/10.1186/s12961-0150074-z, accessed on 10 February 2021. 
for the Transfer of Materials ${ }^{75}$ — all stipulate that the providing research institution retains ownership of the HBM that it provides to the recipient research institution.

\section{(b) The ban on trading in (some) HBM}

The NHA provides for an altruistic, cost-recovery regime for the provision of tissue, blood, blood products or gametes. ${ }^{76}$ The most prominent components of this regime are: (a) a research participant may only receive reimbursement of 'reasonable costs' incurred; (b) apart from research participants, only certain specified kinds of persons and institutions may receive payment for providing tissue, blood, blood products or gametes, and such payment may not exceed an amount which is 'reasonably required to cover the costs' involved in providing such HBM; (c) individual healthcare professionals (who are registered as such) may, however, receive remuneration for professional services rendered related to providing tissue, blood, blood products or gametes; and (d) trade in tissue, blood, blood products or gametes is explicitly made a criminal offence. ${ }^{77}$

Two other statutory documents deal with research participant reimbursement, namely the Use of Human Biological Material Regulations and the Department of Health Guidelines. The Use of Human Biological Material Regulations repeat the NHA's position that research participants who provide HBM may only receive reimbursement of 'reasonable costs' incurred. ${ }^{78}$ The Department of Health Guidelines deal with research participant reimbursement generally, and are not confined to the provision of HBM. However, in this general context, the Department of Health Guidelines state that a 'fair rate of reimbursement should be calculated using the Time, Inconvenience and Expenses (TIE) method'. ${ }^{79}$ Reimbursement for time and inconvenience exceeds the legal parameters specified in the NHA and mirrored in the Use of Human Biological Material Regulations for reimbursing research participants for donating the kinds of HBM contemplated in these statutes respectively. Given that the NHA is primary legislation, this conflict must be resolved

75 'Simple Letter Agreement for the Transfer of Materials' available at https:// autm.net/surveys-and-tools/agreements/material-transfer-agreements/mta-toolkit/nih-mtatemplates, accessed on 10 February 2021; National Institutes of Health Office of Technology Transfer 'Simple Letter Agreement for the Transfer of Materials' available at https://www.ott.nih.gov/sites/default/files/documents/pdfs/slaform.pdf, accessed on 10 February 2021.

76 Section 60 of the NHA.

77 This offence is punishable with a fine, or with imprisonment, or with both a fine and such imprisonment. Regulation 14 of the Use of Human Biological Material Regulations places a limit of ten years on the imprisonment, whereas the NHA places a limit of five years on the imprisonment.

78 Regulation 11 of the Use of Human Biological Material Regulations.

79 Department of Health op cit note 43 at 22. 
in favour of the position in the NHA. Complying with the TIE method as proposed in the Department of Health Guidelines would be illegal in instances of donation of tissue, blood, blood products or gametes. This conflict between key pillars of the statutory scheme is untenable from a policy and a societal impact perspective and should be rectified as a matter of priority.

We now move away from donation by the research participant and consider the transaction where HBM is provided by a research institution. In this context, it is only the NHA's restrictions that apply. Whereas the context of donation by the research participant only involves non-derivative HBM, the context of HBM that is provided by a research institution is not limited to non-derivative HBM but includes the entire universe of nonderivative and derivative HBM. However, the NHA's restrictions only apply to the quartet of tissue, blood, blood products or gametes. All kinds of derivative HBM, with the exception of blood products, are unaffected by the NHA's restrictions. This means that derivative HBM, such as cell lines from tissue and embryonic stem-cell lines, are not subject to the NHA's trade ban. The fact that cell lines from tissue are treated differently from cell lines from blood is arbitrary and highlights how problematic the NHA's inherited lexicon is.

Lastly, it is important to reiterate that the trade ban, to the extent that it is applicable, constitutes an important qualification on the ownership of (and exclusive rights in) HBM, but in no way excludes ownership. For example, cannabis is also subject to a trade ban, but this does not mean that a person cannot own cannabis and use it within the bounds of the law. ${ }^{80}$ The same applies to HBM in the research context.

\section{(c) Ownership of derivatives}

We have already established ${ }^{81}$ that when a research institution lawfully acquires HBM from research participants, the research institution is the owner of such HBM. ${ }^{82}$ The statutory law on this is peremptory, and the actors involved cannot change it through contract. However, the statutory law does not provide for ownership (or exclusive rights) of the derivatives from such donated HBM. At common law, the default position is that the owner of a thing is also the owner of things derived from it, but this is not peremptory and can be changed through agreement. (Another exception to the default position, namely specification, is discussed below.)

80 Private use of cannabis was legalised in Minister of Justice and Constitutional Development v Prince 2018 (6) SA 393 (CC).

81 See our analysis above under the heading 'HBM is susceptible of ownership'.

82 Section 60(4)(a) of the NHA; reg 4 of the General Control Regulations; regs 1 and 11 of the Use of Human Biological Material Regulations; paras 2.8 and 2.12 of the SA MTA. 
This means that in cases where HBM is shared between research institutions, the rights of each party to the MTA - ownership or otherwise - in the transferred HBM, and in any possible derivatives that might be created by the receiving party, can be agreed inter partes. What is peremptory is that the parties must have an MTA in place and that it should use the SA MTA as a 'framework' - that is, to ensure that all the topics covered in the SA MTA are dealt with in the parties' MTA. ${ }^{83}$

It is useful briefly to note how the UBMTA deals with derivatives from transferred HBM. ${ }^{84}$ The UBMTA creates four categories of such derivatives:

- 'Progeny', which is an 'unmodified descendant', for instance a cell from a cell. (When cells are placed in growth medium and chemically stimulated, they will grow and cell division will take place, hence creating more similar cells — a so-called 'cell line'.)

- 'Unmodified Derivative', which is a substance created by the receiving research institution that constitutes an 'unmodified functional subunit or product expressed' by the transferred HBM. An example of an unmodified functional subunit is a cell that is isolated from a tissue biopsy sample, or DNA that is in turn extracted from a cell.

- 'Modification', which is a substance created by the receiving research institution that contains or incorporates the transferred HBM, its Progeny, or Unmodified Derivatives. An example of a modification would be a genetically edited gamete or embryo.

- The last category is other substances created by the receiving research institution through the use of the transferred HBM, its Progeny, or Unmodified Derivatives, but which fall beyond the definitions of Progeny, Unmodified Derivatives, or Modifications.

The providing research institution retains ownership in the transferred HBM, Progeny, Unmodified Derivatives (collectively referred to as the 'Material') and any Material that are contained or incorporated in the Modifications. The receiving research institution is the owner of Modifications (with the exception of the Material contained or incorporated in it) and of the last category mentioned above. What about the intangible derivatives of HBM, such as a genomic sequence or the information about the locus of a gene? An analysis of this question is beyond

83 See our analysis above under the heading 'Perpetual donor ownership?'.

84 The AUTM MTA for Human Tissues (op cit note 73) has almost identical provisions to the UBMTA (op cit note 72) regarding the ownership of derivatives from transferred HBM. The difference is that it does not include 'Progeny' as a distinct category. The NIH Simple Letter Agreement for the Transfer of Materials (op cit note 75) is silent on the topic of ownership of derivatives from transferred HBM. 
the scope of this article but suffice to observe the following: although the providing research institution retains ownership in the Material itself, the UBMTA stipulates that the receiving research institution is free to file patent applications claiming inventions made by it through the use of the Material. This is important from a biopolitical perspective, as it shows that ownership of HBM does not eo ipso translate into ownership of the patents generated by research using such HBM.

\section{(d) Ownership of derivatives and deficient consent}

We now turn our attention to a scenario where a research institution acquires HBM from research participants, but where all the requirements for consent by the research participants are not met. ${ }^{85}$ In this scenario, where the research institution is therefore the possessor rather than the owner, who will own the derivatives that the research institution makes from the HBM? The most probable answer is the research institution, based on specification - a common-law mode of original acquisition of ownership. Where a person makes a thing of a new kind (nova species) out of material that belongs wholly or partly to another, the person (the maker) acquires ownership in the new thing. ${ }^{86}$ Classic examples are wine from another's grapes, a statue from another's gold, and clothes from another's wool. In other words, in this scenario, the research institution will become the owner of the derivates that it makes from using the research participants' $\mathrm{HBM}$ - if such derivatives qualify as a new kind.

When does a thing qualify as a nova species? In post-classical Roman law, the test was whether the new thing could be restored to its original form. ${ }^{87}$ This post-classical Roman law test seems to have survived in South African case law. ${ }^{88}$ This is despite the fact that it is contradicted by the well-known example from Roman-Dutch sources of cups or statues

85 We analyse the requirements for legal consent by the research participant above under the heading 'Acquiring ownership of HBM'.

86 J C Sonnekus \& J L Neels Sakereg Vonnisbundel 2 ed (1994) 305-6. The Roman-Dutch authorities differ on whether good faith is a requirement. However, South African case law requires that the maker must be a bona fide possessor. See Aldine Timber Company v Hlatwayo 1932 TPD 337; S v Riekert 1977 (3) SA $181(\mathrm{~T})$.

87 Kinloch Damph Ltd $v$ Nordvik Salmon Farms Ltd (unreported case no CA29/14/99 of 30 June 1999, available at https://www.casemine.com/judgement/ $u k / 5 a 8 f f 8 e 260 d 03 e 7 f 57 e c f 05 a \#$, accessed on 10 February 2021).

88 See Aldine Timber Co v Hlatwayo supra note 86. The same division of the high court has subsequently obiter expressed doubt about the correctness of Aldine Timber. See Khan v Minister of Law \& Order [1991] 1 All SA 197 (T) at 442J-443A. However, the decision in Aldine Timber has been cited with apparent approval in subsequent cases. See for example Frank \& Hirsch (Pty) Ltd $v$ A Roopanand Brothers (Pty) Ltd 1993 (4) SA 279 (A); Life Diamond Cutting Works (Pty) Ltd v Astra Diamond Manufacturing Ltd [2016] ZAGPJHC 153. 
from another's raw gold or silver, ${ }^{89}$ as such cups and statues can simply be melted down again. Furthermore, in a recent decision by the High Court, Western Cape Division, Cape Town in Special New Fruit Licensing Ltd $v$ Colours Fruit (South Africa) (Pty) Ltd, ${ }^{90}$ the court expressed doubt as to whether the restoration test can always find application. ${ }^{91}$ A sensible suggestion in the academic literature is that the restoration test should be retained as a possible indicium of the new thing being a nova species, but should not be the only or decisive criterion. ${ }^{92}$ If the restoration test is applied to research involving HBM, derivatives such as DNA extracted from a saliva sample, and a new cell line from a tissue sample, would not be capable of being restored to its original form, which would indicate these things are nova species. However, new technologies such as synthetic DNA and $3 \mathrm{D}$ printing of tissue may also impact on the possibility of restoring the original material. An interesting case is a genetically edited embryo. If it were possible to edit it, it should in theory be possible to edit it again to undo the initial edit. The restoration test would therefore not provide support for a genetically edited embryo qualifying as a nova species. A possible alternative test for qualifying as a nova species would be to consider the amount of workmanship and skill involved in making the new thing. ${ }^{93}$ Where relatively novel techniques that require a high level of skill are used to create derivatives from HBM, such as genetically editing an embryo, this test would point toward qualifying as a nova species. However, today's novel technique is tomorrow's routine laboratory task — or it might even be automated. ${ }^{94}$ This amount-of-skill test would therefore disqualify a large swathe of derivatives from being nova species. A third approach that has been suggested in the academic literature is to focus on the value added by the maker and compare it to the value of the material used. If the former is substantially greater than the latter, the new thing qualifies as a nova species. ${ }^{95}$ This value-addition test is different from the amount-of-skill test, as routine and automated processes in a laboratory

89 Cornelius van der Merwe 'Nova species' in E Metzger (ed) Law For All Times: Essays in Memory of David Daube (2004) 96 at 103-4.

90 [2020] 1 All SA 523 (WCC).

91 Ibid para 108.

92 Van der Merwe op cit note 6 para 188 n23.

93 Van der Merwe op cit note 89 at 113.

94 See for example regarding the progress made with DNA sequencing Elaine Mardis 'A brief history of (DNA sequencing) time' 2007 Nature Milestones available at https://doi.org/10.1038/nrg2240, accessed on 10 February 2021; Houriiyah Tegally, James Emmanuel San \& Jennifer Giandhari 'Unlocking the efficiency of genomics laboratories with robotic liquid-handling' (2020) 21(729) BMC Genomics available at https://doi.org/10.1186/s12864-020-07137-1, accessed on 10 February 2021.

95 Van der Merwe op cit note 6 para 188; see also Sonnekus \& Neels op cit note 86 at 306 . 
will not be discounted. They might require little skill, but they certainly have value that can be expressed in financial terms. The other arm of the value-addition test, namely the value of the material used, aims to balance the maker's interests with the interests of the owner of the original material. However, in our present scenario, the value of the material used is nil. Since HBM in its original, non-derivative form can only be donated and cannot be traded, it does not have patrimonial value. It follows that the research institution's value addition will always substantially exceed the value of the material used, and that any derivative produced by a research institution will always be a nova species - and hence owned by the research institution. We suggest that the value-addition test is balanced, fair, and flexible, and ought to be adopted in South African law.

A potential argument against applying specification to the present scenario should be considered. It can be argued that specification was only intended to apply to non-living things, and not to living things. Some kinds of HBM may contain living elements, such as living cells, while other kinds of HBM such as embryos and cell lines are themselves living things. It would then follow that specification is not applicable to many kinds of HBM. The Scottish case of Kinloch Damph Ltd v Nordvik Salmon Farms Ltd ${ }^{96}$ lends some (foreign) authority to this argument. This case dealt with the husbandry of smolt (baby salmon) into adult salmon. Relying on Roman law, the court rejected the argument that animal husbandry qualifies as specification. The court held that ' $[\mathrm{t}]$ here is nothing in the authorities to suggest that the doctrine [of specification] is applicable to the process of growth of living creatures', and that 'the proper scope of the doctrine is in relation to inanimate things or substances created by human effort out of materials which are used up and cease to exist in the process of creation'.

This judgment has been criticised in the academic literature for taking an overly categorical position and for not providing sufficient space for cases where human intervention in the process of growth of living creatures should be rightly considered as specification. ${ }^{97}$ We suggest the following position. As we have mentioned above, the stunning developments in the life sciences over the past few decades have changed how HBM is perceived - it has now become useful. Furthermore, our ancient forebears in Roman times could not have foreseen the impact of modern science on society and the law. As such, one cannot expect the Roman authorities to have made explicit provision for the possible use of living things in specification. As is evident from the emergence of the discipline of biological engineering (or 'bioengineering' in short), we now live in an age where we do use living things to make new things. Therefore, a preoccupation

96 Supra note 87.

97 Van der Merwe op cit note 89 at 113-14. 
with old authorities appears anachronistic and can only have a stultifying effect. Our law must develop in step with the biosciences. Accordingly, while we agree that animal husbandry per se does not create an animal of a nova species, there is no merit in the argument that living things can never be the thing of specification. Our position is strengthened by the recent judgment in Special New Fruit Licensing, where the court accepted that specification can indeed in principle apply to the 'things of natural growth' 98

Would the research participant have a private-law remedy? We first consider unjustified enrichment. In theory, the research participant qua owner of the original material would have an unjustified enrichment claim against the research institution for the loss of the original material. ${ }^{99}$ However, because the original material has no patrimonial value, the research participant would not be able to show patrimonial loss, hence eliminating the possibility of an enrichment claim. Would the research participant have a delictual claim against the research institution? In the event that the research institution intentionally acquired HBM from research participants without meeting the legal requirements for consent, we suggest that the wronged research participants would be able to claim non-patrimonial damages for violation of their dignity using the actio iniuriarum. Note that this remedy is not available if the research institution merely acted negligently or without fault altogether.

Lastly, to conclude our analysis of the deficient-consent scenario, it should be observed that the objective of health research is often the generation of intellectual property rights. The research institution's rights regarding its intellectual property are unaffected by its lack of ownership of the corporeal HBM that was used in research leading to the intellectual property.

\section{CONCLUSION}

Analysing the law on ownership of HBM in the research context is somewhat like building a puzzle with pieces that were added over the course of time. As a consequence, a few pieces do not quite fit, and others are missing. But, for the most part, a picture emerges of a sui generis type of ownership with a unique set of characteristics. Its genesis is when HBM is removed from a research participant. Research participants must be reimbursed for their reasonable costs actually incurred, but not for their time and inconvenience. They cannot sell or barter with their

98 Supra note 90 para 108.

99 Sonnekus \& Neels op cit note 86 at 305; Van der Merwe op cit note 6 para 188. 
HBM - they can only donate it, and only to research institutions. If the donation is done with written informed consent, the research institution becomes the owner of the donated HBM and its derivatives. Yet, the research institution's ownership is always subject to the research participant's non-exclusive right to have the original donated HBM destroyed. Furthermore, the research institution may not use such HBM for any purpose other than research. Within the research context, the research institution may transfer possession and use of the original donated HBM and derivatives to other research institutions, provided that an MTA is in place that uses the SA MTA as a framework. The parties to such an MTA can decide among themselves whether ownership of the material that is transferred and its derivatives will be retained by the provider or also transferred to the receiver. Lastly, while some kinds of HBM are subject to a trade ban, the trade ban does not extend to all kinds of HBM. This, in brief, is the way in which ownership of HBM in the research context is sculpted in extant law.

The pieces of the puzzle that do not fit or are missing are cause for concern from the perspective of legal certainty. Two concerns stand out: (i) the two different lexicons that are used and the gaps in the NHA's lexicon relative to the Use of Human Biological Material Regulations' lexicon; and (ii) the two quasi-statutes, the SA MTA and the Department of Health Guidelines, which both contain elements that are in conflict with the primary legislation - the NHA. Concern (i) can only be addressed through an amendment to the NHA by Parliament, together with a thorough revision of the relevant regulations made in terms of the NHA by the Minister of Health. Concern (ii) might be easier to address. First, the Minister of Health can promulgate a revised version of the SA MTA. A revised version that addresses a variety of shortcomings of the SA MTA, including the perpetual ownership clause, has already been drafted by a group of law academics and is available online. ${ }^{100}$ Secondly, the Department of Health Guidelines were developed by the National Health Research Ethics Council in pursuit of its mandate in terms of the NHA to set norms and standards for health research, ${ }^{101}$ and were subsequently published by the Department of Health. This Council should revise the Guidelines to ensure alignment with the provisions of the NHA.

100 SA MTA version 1.1, available at https://researchspace.ukzn.ac.zal handle/10413/19095, accessed on 10 February 2021.

101 Section 72(6)(c) of the NHA. 